\title{
UNIVERSITYOF
}

FORWARD

THINKING

WESTMINSTER用

WestminsterResearch

http://www.westminster.ac.uk/westminsterresearch

\section{Evaluating coordination and learning within governance: open epistemological issues}

Greenwood, D.

This is a draft chapter. The final version is available in Dotti, N.F. (ed.) Knowledge, Policymaking and Learning for European Cities and Regions: From Research to Practice Cheltenham, Edward Elgar, pp. 219-230, published in 2018.

https://doi.org/10.4337/9781786433640.00029

The material cannot be used for any other purpose without further permission of the publisher, and is for private use only.

The WestminsterResearch online digital archive at the University of Westminster aims to make the research output of the University available to a wider audience. Copyright and Moral Rights remain with the authors and/or copyright owners.

Whilst further distribution of specific materials from within this archive is forbidden, you may freely distribute the URL of WestminsterResearch: ((http://westminsterresearch.wmin.ac.uk/)).

In case of abuse or copyright appearing without permission e-mail repository@westminster.ac.uk 


\title{
20. EVALUATING COORDINATION AND LEARNING WITHIN GOVERNANCE: OPEN EPISTEMOLOGICAL ISSUES
}

\author{
By Dan Greenwood
}

\section{Introduction}

In discussions about governance across various contexts and scales (van Kersbergen et al. 2004), there is wide recognition of the significance of the challenges for policy-makers and strategists of generating, acquiring and appropriately acting upon relevant knowledge in the context of complex, cross-cutting policy challenges (e.g. Voss, Bauknecht, et al. 2006). Complexity and the epistemological challenges to which it gives rise is strongly evident at various 'regional' and 'city regional' scales of governance which of course often overlap and lie in between the national and local scales. The general literature on policy learning provides some key contributions and insights for exploring the implications of epistemological challenges and how they might be addressed ${ }^{1}$. However, reflecting a more general tendency in political science (Greenwood 2016), studies of policy learning tend to refrain from engaging with vital, yet very challenging questions concerning how far wider governance arrangements promote the kind of policy learning that will improve outcomes. Furthermore, as discussed in this book, policy learning at the scale of regional governance has only become a theme of attention relatively recently.

The extensive discussions in political science and related disciplines on the theme of 'governance' and the suggested shift towards 'network' forms of governance have been the subject of considerable discussion in the literatures on regions and city-regional development. The idea of networks suggests that inter-relationships between actors can, rather than taking a hierarchical form, be 'horizontal' and relatively fluid in character, also involving informal kinds of interaction and decision-making. It is often suggested that contemporary governance arrangements, often articulated in terms of 'networks,' involving a range of different actors from the public, private, quasi non-governmental and third sectors, offer a way of addressing epistemological challenges in the face of complex problems, by incorporating and drawing together their contrasting forms of knowledge and expertise (Kooiman 2000: 142). Yet, as Torfing et al (2012) observe, there remains a need to further develop frameworks and criteria for evaluating governance networks. As suggested by Torfing et al, the facilitation of learning is an important potential criterion that is likely to be of central importance to such evaluation.

The question of the role of markets lies at the heart of debates about governance effectiveness across a range of scales. Here, a conceptual and methodological approach is proposed for analysing governance and policy processes that incorporates a political economy focus, considering the relative strengths and weaknesses of market and non-market, political forms of decision-making. Central to the approach is consideration of the relative effectiveness of each type of process in promoting learning. As has been highlighted by the post-positivist turn in policy analysis, the question of what constitutes an 'improved' outcome is of course contested and will depend on the values of the analyst. The approach proposed here seeks to enable closer analysis of how far actors consider governance processes to foster and enable learning, whilst incorporating a post-positivist sensitivity to the contestability of the knowledge and values involved in such analysis.

Section 2 briefly reviews and assesses the literature on policy learning. As this book explores, this body of work offers much potential for the study of regional governance. However, there is need and scope to analyse more closely how actors' substantive understandings of complex policy challenges evolve through processes of learning. It is then argued in Section 3 that, to achieve such

\footnotetext{
${ }^{1}$ See Ch. 4 of this book by Coletti-Dotti-Urso.
} 
analysis, there is significant potential to draw from earlier, classic contributions in political science and political economy, notably the work of Friedrich Hayek and Charles E. Lindblom. These two authors have very different views about the role of political and market arrangements which most effectively promote learning. Yet, it is argued here, there is significant common ground in terms of how they conceptualise processes of coordination, innovation and learning in the context of complexity. Although pre-dating the literature on policy learning, their work anticipates recent departures from instrumentalist, rationalistic approaches to understanding policy learning and evaluation. Section 4 reflects on how Lindblom and Hayek's similar conceptual approaches indicate potential for the study of policy learning to achieve closer engagement with evaluative questions about governance and policy-making.

\section{Analysing policy learning: the focus on process}

The concept of learning has been a central focus of much research on regional development during the last two decades. In the 1990s, scholars brought to the fore notions of the 'learning region', emphasising the vital importance of learning for firms in capitalist market economies (Florida 1995; Morgan 1997) and the political institutions seeking to foster economic development. Since then, this idea has been articulated in terms of the 'new regionalism' (MacLeod 2001) or 'smart regions'. Yet, only more recently has the question of the kind of policy learning needed to promote regional development become the subject of discussion, as set out in this book. This is in the context of increased attention to a range of economic, social and environmental challenges that arise at the city-regional scale (Scott 2001).

Predominant political science approaches to analysing political institutions, notably rational choice approaches, focus on analysing the incentives of actors in different institutional contexts. Yet, aside from incentives-related problems, governance and policy making also involves significant epistemological challenges concerning how to acquire, discover and appropriately act upon a variety of different forms of relevant knowledge for policymaking. This epistemological dimension of governance challenges is conceptually distinct from, yet, in practice closely inter-related with, the incentives dimension (Greenwood 2016). The now substantial literature on policy learning serves to highlight the significance of this epistemological dimension. Serving as the foundations for this literature are the seminal contributions of Hugh Heclo (1974) and Peter Hall (1993), which emphasise that policy-making, aside from the conflicting interests and motives that are inevitably at stake, involves ongoing processes of "collective puzzlement" (1974) and learning. As Waterman et al (2004) later put it, such learning can itself transform the "principal-agent relationships" on which rational choice approaches focus.

Literatures concerned with policy learning offer a range of conceptual tools, including typologies of policy change (Hall 1993), typologies of policy learning (e.g. Glasbergen 1996; Dunlop et al. 2013) and frameworks for analysing the factors that influence policy change (e.g. Sabatier et al. 1993). In a related area of work, Haas (1992) has proposed the notion of "epistemic communities" as a framework for analysing the international communities of knowledge and expertise that shape policy transfer between nation states ${ }^{2}$. The focus of these literatures is upon descriptive analysis and conceptualisation of learning processes, rather than seeking to evaluate these processes in terms of the outcomes to which they lead. Although there has been an extensive recent literature on governance in political science and related disciplines, the question of how to evaluate the effectiveness of contemporary governance networks is an open, emerging question (Torfing et al. 2012). This is reflected in the current lack of literature concerned with assessing how governance can most effectively enable policymakers to learn ways of translating policy goals into practice.

\footnotetext{
${ }^{2}$ See Gerritsen and Dotti in this volume. This point has also been emphasised by recent literatures on reflexive governance (Voss and Kemp 2006)
} 


\section{Political economy perspectives on coordination, innovation and learning}

Aside from these contemporary political science literatures, the theme of learning is prominent in some classic contributions with a political economy orientation. Here, we focus on the work of Friedrich Hayek and Charles E. Lindblom who were both trained as economists. There are important differences between them in terms of the sites of learning that they focus upon and the actors involved, with Hayek focusing on markets and Lindblom on policy studies. Yet, there are important parallels between Hayek and Lindblom in terms of their understanding, at a conceptual level, of epistemological challenges and learning in the face of complexity.

Famously, Hayek was a strong advocate of the market and his work focuses on how markets are an indispensable process for enabling learning by economic actors, including workers, consumers and in particular entrepreneurs. Hayek was a leading member of the Austrian school of economics, a tradition which strongly emphasises the complexities and associated uncertainties faced by economic actors and that economic processes and decisions are inevitably prone to various degrees of failure and imperfection (O'Driscoll et al. 1996). The Austrian tradition emphasises the vital importance of ongoing processes of learning through markets in the face of complexity and change. Building on the contributions of Ludwig von Mises, Hayek's critique of socialist planning especially emphasises the profundity of the epistemological challenges involved in seeking to shape the outcomes of an economy.

Lindblom was an American political scientist and his work provides a seminal, widely cited account of how policy-makers learn through ongoing, inevitably imperfect, processes of adjustment in the face of complexity and change. In contrast with Hayek, Lindblom saw an important role for governments in shaping market outcomes in the face of the inequalities, externalities and failures to which markets give rise. As explained further in the next two sections, Hayek and Lindblom are closely concerned with the challenge of coordination as a central focus for enabling engagement with evaluative questions about the effectiveness of political economic institutions and arrangements. Hence, they were closely concerned with the relative effectiveness of political and market processes in enabling coordination, understanding the facilitation of learning and innovation as an integral part of this challenge.

\section{Hayek on coordination and learning through markets}

Hayek's famous case for classical market liberalism remains steeped in controversy. Yet his account of the indispensability of markets in complex societies, as some of his recent critics have pointed out (e.g. Gamble 1996), offers valuable concepts and insights that remain pertinent to evaluating a range of alternative forms of governance to Hayek's own proposals for market liberalism.

Our particular focus here is on Hayek's conceptualisation of coordination. Although not given an explicit, formal definition by Hayek, coordination can be seen in his work as synonymous with the fundamental economic problem in modern society, that of securing "the best use of resources known to any of the members of society, for ends whose relative importance only these individuals know" (Hayek 1945: 78). He suggests that the outcome of market coordination is like that which would be achieved by a single, all-knowing mind that possessed full knowledge of the different ends of individuals across society, along with knowledge of the economically and technically complex range of production possibilities (Hayek 1945). Hence, coordination means that the actions of individuals take into account the actions being taken by other individuals across society and the actions these individuals might take if one's own actions were different (Kirzner 2000: 136). Such taking into account the actions and preferences of others implies having knowledge about them. Yet, each individual inevitably has relatively limited knowledge, hence, for Hayek, as further explained below, the challenge of coordination involves a fundamentally important knowledge 
related, or 'epistemological' dimension. Achieving coordination requires each individual to be engaged in ongoing learning in the face of the inevitable uncertainty about the available economic alternatives and their impacts.

The starting point for Hayek's understanding of market coordination is an emphasis on the complexity of modern economies ${ }^{3}$. He emphasises that each individual has their own particular goals and preferences concerning the products and services ('final goods') they require to meet these goals. For each particular consumer good, there is a vastly complex range of choices of the means through which these might be produced, involving the allocation of capital goods, technologies, labour and natural resources. Through generating prices, markets serve to encapsulate highly complex information about the inter-relationships between demand and supply for these different final goods and the various possible means of producing them. This information enables economic actors (consumers and producers) to address the choices and trade-offs involved in choosing between them in a way that responds to demand and supply across the economy. A closely related point is that prices, by encapsulating knowledge in this way, serves as a guide for these economic actors as they learn and innovate, identifying new means for more effectively achieving their goals. Monetary prices, as quantitative indicators of economic costs and benefits, are not a perfect guide, especially given the plurality of qualitatively distinct, often incommensurable, goals of individuals across society that must somehow be balanced and prioritised. Just as research in psychology has emphasised the significant role of emotions as inextricably inter-twined with rational thought in the process of learning (Dunlop et al. 2017), so, for Hayek, processes of discovery are driven by intuition, tacit knowledge and a range of motivations that are irreducible to formal, algorithmic calculation (Greenwood 2006, 2007). Market exchange and the prices it generates is nonetheless indispensable to achieving coordination.

The flip side of Hayek's account of market coordination is an emphasis on the epistemological problems that governments face in attempting to substantively shape economic outcomes in the face of complex choices and trade-offs. He applies his critique to both entirely non-market forms of socialist planning and 'mixed' social democratic models that combine markets and various forms of governmental intervention and planning. Hence, he is strongly critical of attempts by politicians to achieve even the substantive goals adopted by more recent, modern liberals, such as 'social justice,' or 'equality of opportunity.' This Hayekian critique is also applicable to goals that are central to current debates in regional governance, such as sustainability and resilience. His critique emphasises the complex, continually changing range of possible policy 'means' for translating such normative, outcome-orientated goals into practice and that the interventions motivated by such goals entail a complex range of potential consequences (Hayek 1944). Choosing the most effective interventions in this context of complexity and change inevitably involves profound epistemological problems (Hayek 1960). Governmental selection of the particular intervention might fail to acquire relevant knowledge or foresee future change hence there is always the danger of decisions leading to negative, unforeseen consequences. Ultimately, for Hayek, the profundity of this danger is such that there is a need to establish clear limits to the role of governments and their interventions in markets. Given his strong commitment to market orientated liberalism, he does not consider the potential for policy actors to achieve ongoing learning in the face of complex policy challenges through non-market political processes.

\section{Lindblom on learning through policymaking}

The work of C.E. Lindblom can be viewed as parallel to that of Hayek in having, as a central focus, the question of the capacity of institutional arrangements to achieve coordination, a challenge which he, like Hayek, understands as involving a fundamental, epistemological dimension. Lindblom, also

\footnotetext{
${ }^{3}$ Hayek's articulation of market coordination (Hayek 1948) builds on the work of Mises (1920) - see (Greenwood 2006, 2007).
} 
like Hayek, starts from a recognition of the qualitatively distinct, often incommensurable, character of the norms and goals that motivate economic actors. Coordination, for both Lindblom and Hayek, is an ongoing process of navigating and discovering complex, dynamically changing, closely intertwined means- ends inter-relationships. Like Hayek, he highlights the significance of the epistemological challenges for policy-makers that are conceptually distinct from, albeit closely inter-twined with, the incentives problems for political systems (Greenwood 2016).

Whereas Hayek focuses on market coordination, Lindblom emphasises the potential for political and non-market institutions to also facilitate coordination. Lindblom accepts the indispensability of the coordinative role of markets and the price mechanism (Dahl et al. 1963: 173; Lindblom 1977: 68). He shares Hayek's concern with the capacity of political processes to address the closely intertwined epistemological and incentives-related dimensions of coordination problems. Yet Lindblom (1977) balances this with more attention and concern than Hayek towards the problems of markets such as the inequalities, externalities and inefficiencies they can generate. He recognises the capacity of non-market, democratic, political institutions, as well as markets, to achieve coordination, by drawing from the plurality of knowledge and expertise held by policy actors and indeed the wider public. His work thus suggests the need for a balanced assessment of the relative strengths and weaknesses of politics and markets in enabling coordination and learning in the face of complexity.

Lindblom's conceptualisation of coordination has a similar epistemological orientation to that of Hayek. Unlike Hayek, he offers an explicit definition of the concept:

\section{"A set of decisions is coordinated if adjustments have been made in it such that the adverse consequences of any one decision for other decisions in the set are to a degree and in some frequency avoided, reduced, counterbalanced, or outweighed" (Lindblom 1965: 154).}

Implicit within this definition, as is made clear by Lindblom's (1965) subsequent discussion in The Intelligence of Democracy, is a recognition that processes of acquiring knowledge through learning are, as for Hayek, of integral importance to achieving coordination. His reference to adverse consequences being counteracted to "some degree," is an implicit acknowledgement that, contrary to the implications of rationalist models, perfect, optimal coordination is unachievable, a point famously emphasised by Lindblom's work as a whole, paralleling the Hayekian critique of neoclassical equilibrium models in economics. Lindblom challenges the assumption of early models policy evaluation models that learning is orientated towards achieving a rational, synoptic understanding of policy problems. Rather, he argues, learning is an ongoing process of adjustment in the face of profoundly complex choices and trade-offs between means for delivering policy goals.

Lindblom emphasises that we cannot precisely assign weightings to our different ends defined in abstract terms, prior to the process of searching for means of realising those ends (Lindblom 1959: 81; Lindblom 1965: 146). Hence Lindblom, like Hayek, departs markedly from treating coordination as the instrumentalist task of identifying means for achieving given ends. Answers to the question of whether coordination is being achieved will ultimately reflect the normatively laden, contested character of these ends. This, combined with the often indeterminate, shifting character of these means for achieving these ends that there can be no definitive measurement of the extent to which coordination has been achieved. Yet both Hayek and Lindblom's work brings to the fore the question of how far different kinds of political and economic decision processes enable actors to acquire knowledge and achieve the ongoing innovation and mutual learning needed in the context of complexity and ongoing change. The work of Lindblom in particular, with his emphasis on the need for balanced consideration of the strengths and weaknesses of political and market processes, suggests a significant potential research agenda engaging with this epistemological dimension of 
governance challenges. Yet, this is a research agenda that would seem to have been somewhat lost by contemporary governance research, with its tendency to focus on processes rather than outcomes and incentives rather than knowledge problems (Greenwood 2016).

\section{Governance evaluation and learning}

Distilling the discussions above, Table 1 summarises the common ground between Hayek and Lindblom in terms of their conceptualisations of complexity and coordination, along with their different views about the particular processes through which such coordination can be achieved. Hence, the works of Hayek and Lindblom are each consistent with a 'post-positivist' approach, in highlighting the need to consider the subjective, contested, partial ways in which different actors perceive or 'frame' governance and policy challenges. Yet, this is combined, in their discussions of coordination problems in political and economic systems, with a concern for how far implementation and outcomes reflect decision-makers' sought after goals. Their respective contributions, with a strong political economy orientation, each suggest that such a focus on outcomes is needed to analyse how political and market processes address complex problems, whilst retaining a sensitivity to the contestable nature of any evaluative conclusions reached. There may of course be a degree of common ground between the normative goals being sought by at least

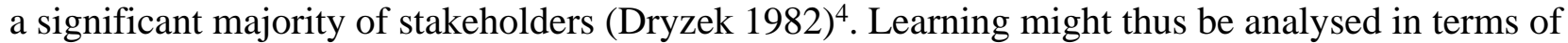
actors achieving shared understandings of the policy tools and strategies required to translate such shared normative goals into practice. This requires attention to how actors acquire, develop and act upon dispersed knowledge concerning the potential and actual outcomes of their decisions. This is in contrast with the process-orientated focus of political science (Greenwood 2016), which is manifest in the policy learning literature. From the perspective of Hayek and Lindblom, it is quite possible for governance to be well coordinated in a process-orientated sense, facilitating learning, yet nonetheless leading to significant problems in terms of their outcomes.

\footnotetext{
${ }^{4}$ A similar approach, combining a concern with the need for evaluation with a post-positivist sensitivity to the contested, value laden nature of knowledge is evident in the work of Frank Fischer (1995, 2009).
} 


\begin{tabular}{|c|c|}
\hline \multicolumn{2}{|r|}{ Complexity } \\
\hline \multirow{4}{*}{$\begin{array}{l}\text { Hayek/ } \\
\text { Lindblom }\end{array}$} & Values, interests or 'ends' of individuals across society \\
\hline & Vast range of consumer goods and services for realising these ends \\
\hline & $\begin{array}{l}\text { Vast range of possible 'means' for producing these goods and services (requiring } \\
\text { allocation of capital goods, technologies, labour, natural resources). }\end{array}$ \\
\hline & Close, dynamic, changing inter-relationship between ends and means \\
\hline \multicolumn{2}{|r|}{ Conceptions of coordination and learning } \\
\hline \multirow{5}{*}{$\begin{array}{l}\text { Hayek/ } \\
\text { Lindblom }\end{array}$} & $\begin{array}{l}\text { Knowledge encapsulation -quantitative units of measurement (e.g. prices), } \\
\text { capturing complex information about costs }\end{array}$ \\
\hline & $\begin{array}{l}\text { Knowledge discovery - learning, innovation, identifying more efficient/ effective } \\
\text { means for achieving ends using prices as a guide }\end{array}$ \\
\hline & $\begin{array}{l}\text { Potential problems of coordination - negative, unintended consequences - in the } \\
\text { face of epistemic limits }\end{array}$ \\
\hline & $\begin{array}{l}\text { Assessing how far coordination has been achieved requires consideration of } \\
\text { outcomes }\end{array}$ \\
\hline & Recognition of the contested, value-laden nature of knowledge \\
\hline \multicolumn{2}{|r|}{ Processes for coordination and learning } \\
\hline Hayek & Markets in the context of generally defined rules, private property rights \\
\hline Lindblom & Politics, policy-making and markets \\
\hline
\end{tabular}

In the field of policy analysis, post-positivist methods such as frame analysis are now ever more widely applied to compare actors' contrasting understandings of governance and policy challenges (Wagenaar 2011). Frame analysis tends to be used to analyse the norms and goals guiding different actors' framings and their understanding of how, in general terms, these ends might be achieved. Yet, Hayek and Lindblom's treatments of coordination challenges in the face of complexity remind us that, to fully evaluate policy decisions and learning requires close consideration of the multifarious, ongoing choices between means for translating these ends into practice, through which these ends themselves evolve. In other words, their work highlights the complex 'economic' dimensions of choice involved in achieving policy goals, with 'economic' being understood in the sense of identifying means for achieving a range of goals that may be qualitatively distinct. As both authors highlight, where governance processes fail to capture knowledge about such economic dimensions of choice, this can become evident in policy decisions leading to negative unintended consequences. Hence, ${ }_{2}$ there is a need to focus on detailed comparisons of how actors frame these economic dimensions of complexity and the potential unintended consequences that might arise from their decisions. This entails an approach that is distinctive, not only from process-orientated political science approaches but also from typical forms of frame analysis, by enabling much closer, thorough analysis of how far governance and policy foster coordination, innovation and learning towards improved policy outcomes.

Evaluative studies of regional development policies have tended to focus on measuring their impacts in terms of economic performance measured in quantitative terms such as employment (Moore et al. 1973; Hopenhayn et al. 1993) or GDP (Bronzini et al. 2006). Reflecting the general lack of research concerned with evaluating the performance of governance networks (Torfing et al. 2012), there is a lack of research involving qualitative evaluation of regional scale governance processes and tools for promoting such economic development. As discussed here, such evaluation 
requires detailed attention to regional stakeholder framings of governance arrangements, policies and tools and their outcomes, with sensitivity to the range of different qualitatively distinct evaluative criteria involved. To study learning requires analysis of how these framings evolve over time. Drawing from Hayek and Lindblom, there is an evident need for close detailed analysis of the evolving framings of the complex economic dimensions of choice and associated uncertainties involved in governance and policy challenges. It might be that, through ongoing processes of policy learning and adjustment, of the kind discussed by Lindblom, actors develop their understanding of these key policy challenges which, in turn, can be seen to yield improved outcomes. The potential research agenda suggested by Lindblom's work over fifty years ago for the evaluation of political and economic arrangements remains to be realised in contemporary governance research. The field of regional development is an especially ripe area for translating this theoretically formulated agenda into empirical research practice.

\section{References}

Bronzini, Raffaello, and Guido de Blasio. 2006. 'Evaluating the impact of investment incentives: The case of Italy's Law 488/1992', Journal of Urban Economics, 60: 327-49.

Dahl, Robert Alan, and Charles Edward Lindblom. 1963. Politics, economics, and welfare : planning and politico-economic systems resolved into basic social processes (Harper: New York).

Dryzek, John. 1982. 'Policy analysis as a hermeneutic activity', Policy Sciences, 14: 309-29.

Dunlop, Claire A., and Claudio M. Radaelli. 2013. 'Systematising Policy Learning: From Monolith to Dimensions', Political Studies, 61: 599-619.

. 2017. 'Learning in the bath-tub: the micro and macro dimensions of the causal relationship between learning and policy change', Policy and Society, 36: 304-19.

Fischer, Frank. 1995. Evaluating public policy (Nelson-Hall: Chicago). . 2009. Democracy and expertise : reorienting policy inquiry (Oxford University Press: Oxford).

Florida, Richard. 1995. 'Toward the learning region', Futures, 27: 527-36.

Gamble, A. 1996. Hayek: the Iron Cage of Liberty (Polity: Cambridge).

Glasbergen, Pieter. 1996. 'Learning to manage the environment.' in W. Lafferty and J. Meadowcroft (eds.), Democracy and the Environment (Edward Elgar: Cheltenham).

Greenwood, Dan. 2006. 'Commensurability and Beyond: from Mises and Neurath to the Future of the Socialist Calculation Debate', Economy and Society, 35: 65-90. 2007. 'Planning and Know-How: the Relationship Between Knowledge and Calculation in Hayek's Case for Markets', Review of Political Economy, 19: 419-33.

. 2016. 'Governance, Coordination and Evaluation: the case for an epistemological focus and a return to C.E. Lindblom', Political Research Quarterly, 2016.

Haas, Peter M. 1992. 'Introduction: Epistemic Communities and International Policy Coordination', International Organization, 46: 1-35.

Hall, Peter A. 1993. 'Policy Paradigms, Social Learning, and the State: The Case of Economic Policymaking in Britain', Comparative Politics, 25: 275-96.

Hayek, F.A. 1944. The Road to Serfdom (Routledge \& Kegan Paul: London).

. 1945. 'The Use of Knowledge in Society.' in F.A. Hayek (ed.), Individualism and Economic Order (Chicago University Press: Chicago).

- 1948. Individualism and Economic Order (University of Chicago Press: Chicago).

Hayek, F.A. . 1960. The Constitution of Liberty (Routledge and Kegan Paul: London).

Heclo, Hugh. 1974. Modern social politics in Britain and Sweden : from relief to income maintenance (Yale University Press: New Haven ; London).

Hopenhayn, Hugo, and Richard Rogerson. 1993. 'Job Turnover and Policy Evaluation: A General Equilibrium Analysis', Journal of Political Economy, 101: 915-38. 
Kirzner, I. M. 2000. The Driving Force of the Market: Essays in Austrian Economics (Routledge: London).

Kooiman, J. 2000. 'Societal Governance; Levels, Models, and Orders of Social-Political Interaction.' in J Pierre (ed.), Debating Governance: Authority, Steering and Democracy (Oxford University Press: Oxford).

Lindblom, C. E. 1959. 'The Science of 'Muddling Through', Public Administration Review, 19: 7988.

Lindblom, Charles E. 1977. Politics and Markets: the World's Political Economic Systems (Basic Books: New York).

Lindblom, Charles Edward. 1965. The intelligence of democracy : decision making through mutual adjustment.

MacLeod, Gordon. 2001. 'New Regionalism Reconsidered: Globalization and the Remaking of Political Economic Space', International Journal of Urban and Regional Research, 25: 80429.

Mises, L von. 1920. 'Economic Calculation in the Socialist Commonwealth.' in F.A. Hayek (ed.), Collectivist Economic Planning: Critical Studies on the Possibilities of Socialism (Routledge: London).

Moore, Barry, and John Rhodes. 1973. 'Evaluating the Effects of British Regional Economic Policy', The Economic Journal, 83: 87-110.

Morgan, Kevin. 1997. 'The Learning Region: Institutions, Innovation and Regional Renewal', Regional Studies, 31: 491-503.

O'Driscoll, Gerald P., Mario J. Rizzo, and Roger W. Garrison. 1996. The economics of time and ignorance (Routledge: London).

Sabatier, P.A., and H.C. Jenkins-Smith. 1993. Policy change and learning: An advocacy coalition approach (Westview Press).

Scott, Allen John. 2001. Global city-regions : trends, theory, policy (Oxford University Press: Oxford).

Torfing, Jacob, Guy Peters, Jon Pierre, and Eva Sørensen. 2012. Interactive governance: advancing the paradigm (Oxford University Press: Oxford).

van Kersbergen, K, and F van Waarden. 2004. 'Governance as a Bridge Between Disciplines', European Journal of Political Research, 43: 143-71.

Voss, J-P, D Bauknecht, and René Kemp. 2006. Reflexive governance for sustainable development (Edward Elgar: Cheltenham, Glos, UK).

Voss, Jan-Peter, and René Kemp. 2006. 'Reflexive governance for sustainable development.' in JanPeter Voss, Dierk Bauknecht and René Kemp (eds.), Reflexive governance for sustainable development (Edward Elgar: Cheltenham, Glos, UK ; Northampton, MA).

Wagenaar, H. 2011. Meaning in action : interpretation and dialogue in policy analysis (M.E. Sharpe: Armonk, N.Y).

Waterman, Richard W., Amelia A. Rouse, and Robert Wright. 2004. Bureaucrats, politics, and the environment (University of Pittsburgh Press: Pittsburgh). 